\title{
The effects of brand equity, price, and brand proliferation on new product performance through product trial: evidence from FMCG industry in Indonesia
}

\author{
Winson Sinurat ${ }^{1}$ and I Made Bayu Dirgantara1 \\ ${ }^{1}$ Management Department, Faculty of Economics and Business, Universitas Diponegoro, Indonesia
}

\begin{tabular}{ll}
\hline Abstract & Business competition in fast-moving consumer goods (FMCG) products in Indonesia has \\
increased due to industry growth in this sector. Companies must create new marketing \\
strategies to maintain and gather a broader market share. The purpose of this study is to \\
analyze the effects of brand equity, price, and brand proliferation on new product \\
performance of FMCG products through product trial. This study uses quantitative analysis, \\
which uses data analysis tools SPSS 26) to analyze the data with PROCESS macro \\
analysis to analyze the mediator variables. This study showed that brand equity, product \\
quality, and brand proliferation had a positive and significant effect on new product \\
performance. The PROCESS analysis results also show mediating effects between brand \\
equity, price, and brand proliferation on new product performance through product trial. \\
These results also show that brand equity, price, and brand proliferation can predict new \\
product performance in the FMCG industry in Indonesia.
\end{tabular}

Keywords

brand equity; price; brand proliferation; trial; product performance; fast moving consumer goods (FMCG) industry

\section{INTRODUCTION}

Fast-moving consumer goods (FMCG) are quickly sold out and generally consist of products used in everyday needs (Malhotra, 2010). FMCG can also be categorized as products sold in a short time and have a relatively low price. Consumers can easily find FMCG products, and they do not require much effort to find them. FMCG products, such as soap, shampoo, food, beverage, detergent, and medicine, are easy to find in supermarkets.

According to the data obtained from Kantar World Panel, Fast Moving Consumer Goods (FMCG) industry in Indonesia has indicated a significant increase. In Indonesia, there are many companies engaged in FMCG, both local and multinational. In recent time, the FMCG industry has been a favourite field for job seekers, ranging from fresh graduates to experienced ones. The big names of companies engaged in the industry are one of the attractions.

With the phenomenon of FMCG industry growth that continues, companies engaged in this industry will try to compete in getting increasingly consumptive customers.

With the phenomenon of FMCG industry growth that continues, companies engaged in this industry will try to compete in getting increasingly consumptive customers. One of the things that companies often do to compete is to innovate.

Product innovation is defined as a process of observing consumers find new things that can meet the wants and needs of consumers (Manders et al., 2016). In pursuing innovation, companies need to pay attention to the dimensions of the product where there are three dimensions of a product innovation Pratiwi (2016), including: (1) line extension which refer to a product that is produced by a company that varies, so that the product makes it easy for consumers to find products according to their needs; (2) new product (me too product) which refer to a new product for the company but is considered not new to the market; and (3) a truly new product (new - to - the - world - product) which refer to a new product for both the company and the market. 
In launching new products, companies will measure the performance of their new products. Product performance is described as a response to a product through external assessments within the scope of the product (Cheng et al., 2014). The performance of its constituent components determines the performance of a product.

Product performance variables are related to three categories: design properties such as function, shape, surface, material, and dimensions, then internal properties such as strength, stiffness, hardness, elasticity, corrosion, endurance, and the last, external properties such as ergonomics, aesthetics, reliability, care, and safety (Cui and Wu, 2016). Therefore, the industry will pay attention to these three aspects in the creation of a new product. However, most customers only focus on the external characteristics of the product. Thus, performance can be defined as a "vector of performance variables", where each variable can be measured from a product or its elements (Cui and Wu, 2016).

Measurement of the success of a new product can be calculated through the variables that are components in the success. These variables can be in the form of brand equity, prices, brand proliferation, and product trials (Hoskins and Griffin, 2019). Brand equity has a significant influence on the literature because literature later shows that branded products can generate higher value than unbranded products (Davcik et al., 2015). Brand equity affects market perceptions in many ways (Tzokas et al., 2015). Brands with high equity can be associated with quality signals that can promote new product trials by reducing the risk of adoption by consumers (Yalcinkaya and Aktekin, 2015). Thus, the increase in brand equity allows the new product launched by the company to be well received by consumers.

In addition, in launching a new product, it is necessary to pay attention to the relative price point of the brand against other brands. This is because price placement is related to product quality (Gorodnichenko, 2014). A higher-than-average brand price will lead to the placement of a high-price brand which will result in reduced sales, as there are fewer customers in the high-price segment than in the low-price. However, such placement can help a brand maintain a high- quality appeal (Markman and Waldron, 2014).

Companies with a high brand position can also lead to more innovation than a low position brand that stays in cost leadership with little margin available to invest in the product. Placing a product on the high end can also improve the performance of a new product, even when product quality remains constant. This is because product placement in the upper class can create an advantage in signal quality (Gorodnichenko, 2014). Thus, despite a decrease in the number of potential customers, placing at a high price can give the brand an overall market advantage because the new product can be perceived as being of higher quality.

In the performance of new products, brand proliferation will also affect success. Brands with high brand proliferation in a category can create the ability to innovate and gain market acceptance. Organizational learning theory suggests that managers can learn from previous innovation efforts and incorporate that knowledge into new product development practices. This allows more brands that can be adapted to new product offerings to market needs (Hoskins and Griffin, 2019).

In addition, managers of more developed brands can obtain more comprehensive market information (demography, buying behavior), which can then lead to a better ability to meet diverse consumer needs (Barlow, 2018). Therefore, brand proliferation can strengthen the brand's appeal through. Thus, brand proliferation has both potentially positive and negative effects.

A very prosperous new product can yield many benefits. Previous research has found that the value derived from introducing a new product comes from the value of the company itself. Thus, firm value should be used in measuring the performance of new products (Mogaji and Danbury, 2017).

Firm value can be in the form of brand equity, price, and brand proliferation. After the company introduces a new product to the market, the customer must assess whether the benefits of the new product are good enough so that the customer can learn the lessons that will take time and effort (Alhaddad, 2015). In introducing new products, the brand must have distinctive attributes and be easily recognized by many people. This is because, in the buying 
process, customers will find it easier to evaluate product attributes.

On the other hand, some customers need to feel the benefits of a new product first or even follow recommendations from other customers before trying a product (Yalcinkaya and Aktekin, 2015). Other research shows that when a new product has a low image, price position, or category, the success of the new product will also be low (Asberg, 2015). Companies need to know market needs, listen to these needs, and incorporate them into the new product development process (Story et al., 2015).

Behind the growing phenomenon of the FMCG industry in Indonesia, competition in this industry will become more competitive. Companies in this industry will try to stay afloat and try to win the competition. One of the efforts that the company can make is to innovate by launching new products. However, although new product launches have a positive impact, new products can also harm the company. This can be seen through the phenomenon carried out by leading companies such as Pepsi, which issued a new product, namely Pepsi Crystal and Oreo, which issued a Watermelon Oreo product with a negative response from consumers. This study aims to examine and analyze the effect of brand equity, price, and brand proliferation on the performance of a new product through product trial as a mediator in the Fast-Moving Consumer Goods (FMCG) industry in Indonesia.

\section{LITERATURE REVIEW AND HYPOTHESES DEVELOPMENT}

\section{Brand equity}

In launching new products, products from companies that many consumers have known tend to get more success when compared to new products launched by companies from unknown companies. Therefore, branded products can produce more values than non-branded products (Davcik et al., 2015). For example, brands with high equity have perceived brand authority, consistency, and innovative image excellence (Cui and $\mathrm{Wu}, 2016$ ). In addition, brands with high equity can also be linked to quality signals that can help promote new products by reducing the risk of adoption by consumers (Yalcinkaya and Actekin, 2015).
In purchasing new products, consumers will evaluate a brand. Consumers will create a relationship between the customer and the brand, increasing consumer loyalty to specific brands (Hunt, 2019). Therefore, when a consumer purchases a branded product, the consumer remembers the brand in his mind. This is because the brand adds value to the product in the minds of consumers (Severi and Ling, 2013).

In competition, brand equity is a valuable asset for a company because brand equity is obtained through consumer confidence in the brand. Competitors can easily imitate products because they are tangible, whereas brand equity is not easily imitated because it is intangible (Wang and Finn, 2012).

In increasing competitive advantage, companies implement various strategies. One strategy that can be used as an alternative to increasing brand equity is introducing new products to the market using brands that have been previously known or known as brand extensions (Voss and Mohan, 2016). Through brand extensions, companies can gain profits in terms of their corporate image. Brand extension can build a positive brand image (Mohan and Sequeira, 2012). One of the advantages of a brand extension strategy is to reduce marketing costs by utilizing brand equity from previous products. However, companies still cannot rule out promotions when launching new products (Matarid et al., 2014).

Even though the company has gained substantial brand equity through brand extension, the company still has to carry out promotions. Promotion is one of the essential factors in the marketing process (Hunt, 2019). Increasing brand equity in the company can affect customer loyalty to a brand. Some researchers acknowledge a positive relationship between brand equity and brand loyalty (Molinillo et al., 2019).

\section{Price}

Price is a critical component attached to a product. According to Santoso (2016), price is a particular value that must be issued or paid for the value of a product or service used or purchased. Price is one of the things that consumers consider in making purchasing decisions. By issuing the value to be paid, the customer has paid or bought 
a product or service for the customer's needs. Alfred (2013) argues that price is one of the costs faced by consumers, and the price is one component that plays an essential role in influencing consumer purchasing decisions. Prices are usually determined by combining costs incurred by the company to produce a product, which is added to the profit margins that the company wants to obtain.

Price can be interpreted as the amount of money and/or other aspects needed for specific needs and needed to get a product (Tjiptono et al., 2020). By spending money in accordance with the price determined by the seller, consumers will get the product following their wishes.

Merriam-Webster (2020) explains that price is the amount of money needed to get a combination of products and services. So, the price is the unit needed by consumers to spend a predetermined amount of money to get a product in combination with the product itself and the services that the consumer will obtain. Weenas (2013) also explains that price is money used as a medium of exchange for goods or services and can also help determine the value of products in the minds of consumers. Price is often used as a measure of the quality of goods or services. Consumers will usually estimate the quality of a product based on the price given to the product. Therefore, price is considered as a determinant of the product value in the minds of consumers.

Setting a reasonable and appropriate price can provide various benefits to the company in the market and within the company itself. For example, companies can obtain benefits derived from reasonable prices by determining prices that can cover the costs or inputs needed to produce output and provide profit margins that companies want to achieve while also considering the market and consumer conditions.

Prices are more flexible than product demonstrations. This happens when companies can quickly and easily change their prices, for example, price-fixing on internet sites (Gorodnichenko, 2014).

However, some strategies increase product demonstrations or trials more than price-fixing. For example, car manufacturers generally carry out the strategy by giving car dealers a little flexibility in price adjustments but much flexibility in the test drive and showroom experience (Cato, 2014).

\section{Brand proliferation}

Brand proliferation is the number of products that have been offered by a brand in a category of goods or services. (Hoskins and Griffin, 2019). In competition, companies tend to have the advantage of a product brand in one line. In general, brands control most of their sales from only one superior product (Tanusondjaja et al., 2018). This can be caused by the company succeeding in increasing brand equity in the product alone through the strategy adopted by the company. In addition, this can be caused by the company focusing on just one product in a certain period. On the other hand, when a company launches a product, the company must consider many things because one product failure can negatively affect the rest of the offered brand category (Barlow, 2018).

Brand proliferation can also occur in service companies such as airlines. Brand proliferation like this was done to respond to new competitors who developed the traditional airline business model. As such, companies must focus more on the brand value proposition needed by airlines that want to remain a vital entity (So et al., 2017).

Brand proliferation can benefit the company. An exciting aspect of the brand proliferation strategy is that this strategy can be applied to large and small brands at high or low positions. Through brand proliferation, a brand can grow significantly. Brand proliferation is usually done by doing one new product at a time (Hoskins and Griffin, 2019).

On the other hand, brand proliferation has positive effects and negative effects that can occur. Positive effects can be in the form of increased trust by consumers in companies and increased brand equity. Meanwhile, negative effects can be in product launch failures because they are not accepted by consumers and reduce the company's image. Therefore, the combination of these two effects can be controversial, and both of these effects have a vital supporting factor (Hoskins and Griffin, 2019).

Meanwhile, filling the brand's product line with the number of available products (brand proliferation) allows the brand to experience an increase in new product trials and overall increase in sales. Therefore, it is important for companies to only launch products that 
maintain brand image prices when launching new products (Hoskins and Griffin, 2019).

\section{Product trial}

Product trials are an important and effective marketing method for promoting and increasing consumer confidence about new products. This has been proven in studies of marketing, consumer psychology, and information systems that consistently show that product trial is a powerful mechanism for directing consumers' views of products or services (Huang and Korfiatis, 2015).

In a new product launch, only brand equity and the house of brands can last for a while of the trial until repeated purchases. These two factors increase sales initially and maintain sales increases over time (Hoskins and Griffin, 2019.) The overall success of new products in brands with a higher price position and brand proliferation in a category is generally obtained by encouraging intensive product testing.

New products from brands with brand equity and higher brand price positions tend to be significantly profitable. However, this advantage is only in the aspect of product acceptance by the market. This can also be said to be advantageous compared to products with brand new ones or brands with lower equity or prices. These brands have several market advantages, including signaling higher quality and product reliability and reducing consumer adoption risk, and explicitly encouraging an intention to try the product (Yalcinkaya and Actekin, 2015). This study indicates that the brand strategy has an overall relationship with sales increases in the full one-year period and an increase in the level of new product trials and a higher level of reparation.

Meanwhile, adding brand product lines to a more significant number of available products enables brands to experience an increase in new product trials and overall sales increases, and thus companies must commercialize products that maintain brand image prices when testing products.

An example of product trials is the sale of cigarettes in the United States. Evidence from several reports made by Surgeon General in the United States supports the idea that tobacco advertising and promotion can influence perceptions of risk, product trials, and use of tobacco products in adults and adolescents (Smith et al., 2015).
With the increasing number of tobacco companies expanding their product lines to include e-cigarettes and the increasing number of independent electronic cigarette producers in the market, there is concern that an increase in advertising, coupled with an increase in inventory, could affect current tobacco consumers. This can also influence non-consumers (including those who have never been and users before) to consider testing and adopting e-cigarettes. Findings from this study show that exposure to advertisements for e-cigarettes can increase interest in e-cigarette trials, especially among smokers (Smith et al., 2015).

\section{New product performance}

Previously, there was a research that identified the relationship between innovation and product performance. The research adds to the existing literature by examining more complex models of the relationship between innovation and performance of a curved company's products and depend on environmental factors of organizational and external tasks (Story et al., 2015).

For companies that innovate in emerging markets, market orientation enables companies to target better innovative new products for customers' needs and preferences and open new and underserved market gaps. This supports the success of innovative new product offerings. The main point of the findings in this study suggests that companies in emerging markets may be utilizing their institutional environment to their advantage in different ways (Story et al., 2015).

This finding also shows that product innovation activities can improve performance when companies suppress market-oriented principles in both developed and developing markets. Thus, companies that invest more in market orientation activities can increase their innovation activities better.

Expansion of the company's brand can affect the results of the performance of new products. This is because consumers can see that the brand can develop and compete. But some researchers emphasize that ongoing brand enhancement can have a negative impact on companies. Overall, the marketing field is cautious in determining decisions on the growth of the company's 
brand. This is because excessive brand growth can lead to negative results for new product performance and company image and brand equity (Urde, 2016).

Previous research also believes that the effect of the performance is more substantial during the product trial period than after that, namely in the repurchase or continuous period. In addition, in this study, it was found that brand extension across categories would positively impact the performance of new products (Hoskins and Griffin, 2019).

The positive impact of the brand extension identified on the performance of the new product will be more on the product trial period than the consumer repurchase period and adoption period. One strategy to strengthen the performance of new products is to do promotions. This can be done by improving the product in terms of features and appearance to strengthen promotional tactics inside and outside the store. As such, previous research has shown the positive impact that both types of promotional tactics can have on the performance of new products (Mogaji and Danbury, 2017).

\section{The effect of brand equity on new product performance}

Brand equity has a significant influence in the literature because this variable shows the strength of the brand in the market (Ganesh et al., 2018). In addition, there is literature which then shows that branded products can generate value above unbranded products (Davcik et al., 2015).

Brand equity can influence market perceptions in many ways. One of them is by providing a signal of quality that reflects the quality of a product being offered. Brands with high equity can be associated with quality signals that can help promote new product trials by reducing the risk of adoption by consumers (Yalcinkaya and Aktekin, 2015). For example, in the sportswear industry, products with high brand equity have authority, consistency, and excellence in innovation (Cui and Wu, 2016).

Thus, increasing brand equity allows new products launched by companies to be well received by consumers (O'Reilly, 2017). This can also lead to a broader market share and higher loyalty among customers (Molinillo et al., 2019). Therefore, products launched by companies with higher brand equity tend to have high product performance (Brunner et al., 2016). We predict that there is an indirect influence between brand equity on the performance of new products.

H1: Brand equity has an indirect effect on the performance of new products in the FMCG industry in Indonesia.

\section{The influence of price on new product performance}

In previous studies, attention was focused more on brand placement. This involves marketing aspects of a particular brand image to customers (Mohan and Sequeira, 2012). One of the most common focuses when undertaking branding is the price point relative to other brands. This is because price placement is related to product quality (Gorodnichenko, 2014).

Higher than average brand prices will result in high brand pricing, resulting in fewer sales because fewer customers are in the high-priced segment than the low-priced ones. However thus, such placement can help a brand maintain high-quality appeal (Markman and Waldron, 2014).

A company with a high brand position can also lead to more increased innovation than a brand in a low position that persists in the cost leadership with little available margin to invest in the product. Furthermore, placing products at the top of the class can also improve the performance of new products, even when product quality remains constant. This is because the placement of products in the upper class can create advantages in quality signals (Yalcinkaya and Aktekin, 2015).

Thus, despite a decrease in the number of potential customers, placing at a high price can give the brand an overall market advantage as the new product can be higher quality. In addition, based on Anggana (2016) research, there is an indirect effect of price on new product performance.

H2: Price has an indirect effect on the performance of new products in the FMCG industry in Indonesia. 
Table 1.

Respondent characteristics

\begin{tabular}{ccc}
\hline \multicolumn{3}{c}{ Gender } \\
\hline Category & Percentage & Frequency \\
\hline Male & $39,8 \%$ & 45 \\
Female & $60,2 \%$ & 68 \\
\hline \multicolumn{3}{c}{ Age } \\
\hline Category & Percentage & Frequency \\
\hline $11-20$ & $49,6 \%$ & 56 \\
$>30$ & $48,7 \%$ & 55 \\
\hline
\end{tabular}

\section{The relationship between brand proliferation and new product performance}

Brands with high brand proliferation in a category can create the ability to innovate and excel in market acceptance. In addition, organizational learning theory suggests that managers can learn past innovation efforts and incorporate that knowledge into new product development practices. This allows creation of more brands that can be adapted to new product offerings to meet market needs (Severo et al., 2017).

In addition, managers of more developed brands can obtain more comprehensive market information (demographics, purchasing behavior) which can then lead to a better ability to meet the diverse needs of consumers (Hoskins and Griffin, 2019).

Therefore, brand proliferation can strengthen brand attractiveness through competence, so that if a brand releases a lot of products, this can attract consumers when a company releases a new product (Hoskins and Griffin, 2019). Thus, brand proliferation has an indirect effect on the performance of new products.

H3: Brand Proliferation has an indirect effect on the performance of new products in the FMCG industry in Indonesia.

\section{METHODS}

\section{Data collection}

In collecting the data, we distributed questionnaires. From the distribution of questionnaires, 164 respondents were obtained, of which 113 respondents had met the required sample criteria, namely having purchased FMCG products once and living in Indonesia, and 51 respondents did not meet the criteria of this study. As presented in Table 1, the majority of the respondents in this study were female, age between 11-20 years old, with an income range of $\mathrm{Rp}$. 500.000,- - Rp.1.500.000,-.

\section{Measurements}

The measures for all constructs in this study were adapted from previous research. For example, brand equity was measured using five items (Aqmarina, 2014, Yang, 2018). Price was measured using four items (Djatmiko dan Pradana, 2016) dan (Brata et al., 2017). Brand Proliferation was measured using four items ( Hoskins dan Griffin, 2019, de Haas et al., 2018, Srisomthavil and Assarut, 2018). Meanwhile, product trial was measured using four items (Sun et al., 2017), and new product performance used four items (Klyatis, 2015). All sclaes are measured using with 5 points Likert scale.

\section{RESULTS AND DISCUSSION}

In this study, the analysis was carried out using PROCESS analysis to analyze a mediating effect. PROCESS analysis is a macro created by Andrew F. Hayes (2018) that can be installed on SPSS that can be used to do moderator and mediator analysis or both simultaneously. The advantage of PROCESS analysis is that researchers only need to do one analysis to see the effects of moderation or mediation. In addition, PROCESS can also be used to create more complex models with more than one moderator or mediator variable. To measure the effects of mediation, the model used in 
Table 2.

Summary of Hyphoteses Testing Results

\begin{tabular}{lccc}
\hline \multirow{2}{*}{ Hyphoteses } & \multicolumn{3}{c}{ Indirect Effect } \\
\cline { 2 - 4 } & BootLLCI & BootULCI & Effect \\
\hline $\begin{array}{l}\text { H1: Brand equity have an indirect effect on } \\
\text { new products performance }\end{array}$ & $0,0538^{*}$ & $0,1759^{*}$ & 0,2094 \\
$\begin{array}{l}\text { H2: Price have an indirect effect on new } \\
\text { products performance }\end{array}$ & $0,0357^{*}$ & $0,1576^{*}$ & $0,1888$. \\
$\begin{array}{l}\text { H3: Brand proliferation have an indirect } \\
\text { effect on new products performance }\end{array}$ & $0,0654^{*}$ & $0,1859^{*}$ & $0,2478$. \\
\hline
\end{tabular}

*Significant if Boot $\mathrm{LLCl}$ and BootULCi is not 0

this analysis is model number four. According to Hayes (2018), if path a and path $b$ are significant by having $p<0.05$, it can be concluded that there is an indirect effect or mediation. In addition, if the results of the BootLLCl and BootULCI range values on the indirect effect do not show zero then it can also be concluded that there is an indirect or mediating effect. The summary of hypothesis testing for our study is presented in Table 2.

\section{The effect of brand equity on new product performance}

Based on the analysis results, hypothesis one $(\mathrm{H} 1)$ can be accepted. This can be seen from path $a$ and path $b$, which are significant with $p$ values $<0.05$, which are 0.001 and 0.0000 . In addition, the results of the BootLLCI and BootULCI range values on the indirect effect do not show the number 0 but rather 0.0538 and 0.1759 . From these results, it can be concluded that there is an indirect or significant mediation effect of brand equity variable on new product performance. In addition, it can be seen that the indirect effect of brand equity variable on new product performance through product trial is equal to 0.2094 .

\section{The effect of price on new product performance}

Based on the analysis results, hypothesis two (H2) can be accepted. This can be seen from the results of path a and path $b$, which are significant with $p$ values $<0.05$, which are 0.0006 and 0.0000 . In addition, the results of the BootLLCI and BootULCI range values on the indirect effect do not show the number 0 but 0.0357 and 0.1576 . From these results, there is an indirect effect or significant mediation of the price variable on new product performance. In addition, it can be seen that the indirect effect of the price variable on new product performance through product trial is 0.1888 .

\section{The effect of brand proliferation on the performance of new products}

Based on the results of the analysis, hypothesis three $(\mathrm{H} 3)$ can be accepted. This can be seen from the results of path a and path $b$ that are significant with $p$ values $<0.05$, which are 0.000 and 0.0000 . In addition, the results of the BootLLCI and BootULCI range values on the indirect effect do not show the number 0 but rather 0.0654 and 0.1859 . From these results, there is an indirect effect or significant mediation of brand proliferation variable on new product performance. In addition, it can be seen that the indirect effect of the brand proliferation variable on new product performance through product trial is 0.2478 .

\section{The role of product trial as a mediation variable}

Based on the analysis conducted, it can be seen that product trial variable has a very important role in launching new products. This means that the independent variables, brand equity, price, and brand proliferation, will be maximized if mediated by product trial.

From the previous analysis, it can be concluded that the trial of new products as a mediating variable has a very large influence. If all independent variables are 
affected by product trial as a mediator, new product performance will be greater than if they were not affected by product trials. If mediated through product trial, the influence of each independent variable can exceed three times the direct effect.

There is an indirect effect between brand equity on new product performance. These results are in line with research conducted by Hoskins and Griffin (2019), which shows that brand equity has an indirect and significant effect on the performance of new products. Furthermore, it can also be said that if FMCG products' brand equity has better brand awareness, brand characteristics, logo, and experience and comes from leading companies, the performance of new products in the FMCG industry in Indonesia will increase.

There is also an indirect effect between price on new product performance. These results are in line with research conducted by Anggana (2016) which shows that price has an indirect and significant effect on the performance of new products. Moreover, it can also be said that the prices for FMCG products are affordable and follow the quality and have discounted prices and price advantage with competing products. The performance of new products in the FMCG industry in Indonesia will increase.

The result shows that there is an indirect effect between brand proliferation on the performance of new products. These results are in line with the research conducted by Haas et al. (2018), which shows that brand proliferation has an indirect and significant effect on the performance of new products. Furthermore, it can also be said that if the brand proliferation on FMCG products offered has an increasing number and variety of products and is increasingly used by the public and can develop in the future, the performance of new products in the future FMCG industry in Indonesia will increase.

The most dominant variable in indirectly influencing this study's new product performance variable is the brand proliferation variable. This can be seen from the PROCESS analysis results, which indicate that brand proliferation has the most dominant indirect influence on the performance of new products. So it can be concluded that consumers are very concerned about brand proliferation in trying or consuming new products. Since all independent variables are influenced by product trial as a mediator, the effect on new product performance will be greater than if not influenced by product trial.

\section{CONCLUSION}

This research indeed cannot be separated from limitations. Some limitations in this study are that this study only applies to consumers of FMCG products in Indonesia alone so that if research is carried out in different countries, the study results will also be different. In addition, when viewed from other perspectives or theories, various other independent variables can be tested for their effect on new product performance. Other variables outside this study can be tested on the same object (FMCG products).

Suggestions that can be considered for future research are that future researchers are expected to research other areas that this research has not reached to get more results. In addition, future research is expected to add other independent variables that can be tested for effects on new product performance. For further research, other variables can also added to be tested on the same object and can be enriched qualitatively.

\section{REFERENCES}

Alfred, O. (2013). "Influences of Price And Quality On Consumer Purchase Of Mobile Phone In The Kumasi Metropolis In Ghana A Comparative Study". Semantic Scholar, 5(1), 179-199.

Aqmarina, S., Kumadji, S., \& Kusumawati, A. (2014). "Pengaruh Celebrity Endorser terhadap Citra Merek serta Dampaknya pada Keputusan Pembelian (Survei pada Mahasiswi Fakultas IImu Administrasi Universitas Brawijaya Angkatan 2013 dan 2014 Konsumen Produk Kosmetik Wardah)", 39(2), 1-10.

Barlow, M.A., Verhaal, J.C. and Hoskins, J.D. (2018). "Guilty by association: productlevel category stigma and audience expectations in the US craft beer industry". Journal of Management, 44(7), 2934-2960.

Cato, J.2014. "Car dealers profit-but not as much as you'd think". Globe and Mail, 1:4, $\quad$ h..n.p, http://www.theglobeandmail.com/globedrive/news/cato-car-dealers-profit-butnot-as-much-as-youd- 
think/article16188656/. Diakses tanggal 9 Januari 2020.

Cheng, C.C.J., Yang, C-I., Sheu, C. (2014). “The link between eco-innovation and business performance: a Taiwanese industry context". Journal of Cleaner Production, 64, 81-90.

Cui, Anna S., and Fang Wu. 2016. "Utilizing Customer Knowledge in Innovation: Antecedents and Impact of Customer Involvement on New Product Performance." Journal of the Academy of Marketing Science, 44(4), 516-38.

Davcik, N.S., da Silva, R.V. and Hair, J.F. (2015). "Towards a unified theory of brand equity: conceptualizations, taxonomy and avenues for future research". Journal of Product \& Brand Management, 24(1), 3-17.

de Haas, S., Herold, D., \& Thomas Schäfer, J. (2018). "Entry deterrence due to brand proliferation: Empirical evidence from the German interurban bus industry." Magkspapers, 4(2), 31-34.

Djatmiko, T., \& Pradana, R. (2016). "Brand Image and Product Price; Its Impact for Samsung Smartphone Purchasing Decision." Procedia - Social and Behavioral Sciences, 21(9), 221-227.

Gorodnichenko Y., Sheremirov V., Talavera O. (2014). "Price setting in online markets: Does it click?". National Bureau of Economic Research, Cambridge, MA, 6(4), 48-56.

Hair, Jr et.al. (2010). Multivariate Data Analysis (7th ed). United States : Pearson.

Hayes, A. F. (2018). Introduction to Mediation, Moderation, and Conditional Process Analysis, Second Edition (Methodology in the Social Sciences). New York, NY: The Guilford Press.

Hoskins, J. D., \& Griffin, A. (2019). "New product performance advantages for extending large, established fast moving consumer goods (FMCG) brands". Journal of Product and Brand Management, 28(7), 812-829.

Huang, G., \& Korfiatis, N. (2015). "Trying Before Buying: The Moderating Role of Online Reviews in Trial Attitude Formation Toward Mobile Applications". International Journal of Electronic Commerce, 19(4), 11-77.

Hunt, S. D. (2019). "The ethics of branding, customer-brand relationships, brandequity strategy, and branding as a societal institution". Journal of Business Research, 95, 408-416.

Kantar World Panel, 2019. "Pertumbuhan Industri FMCG di Indonesia pada tahun 20162019"

http://www.kantarworldpanel.com. Diakses 24 Desember 2019

Klyatis, L. (2015). "Introduction to Successful Predicting of Product Performance (Reliability, Durability, Safety, Quality, Recalls, Profit, Life Cycle Cost, and Others)". SAE Technical Papers, 9(5), 60-93

Malhotra, N. K. (2010). Marketing research: An applied orientation (6th ed.). London: Pearson Education

Manders, B., De Vries, H. J., \& Blind, K. (2016). "ISO 9001 and product innovation: A literature review and research framework". Technovation, 48-49, 4155.

Matarid, N. M., Youssef, M. A. M., \& Alsoud, G. A. (2014). "The Impact of Brand Extension Strategy on the Brand Equity of Fast Moving Consumer Goods (FMCG) in Egypt". European Journal of Business and Management, 6(21), 154164.

Mogaji, E. and Danbury, A. (2017). "Making the brand appealing: advertising strategies and consumers' attitudes towards UK retail bank brands". Journal of Product \& Brand Management, 26(6), 531-544.

Mohan, B. C., \& Sequeira, A. H. (2012). "Customer-Based Brand Equity in the Fast-Moving Consumer Goods Industry in India". International Journal of Management, 1(4), 1-19.

Mohan, M., Jimenez, F.R., Brown, B.P. and Cantrell, C. (2017). "Brand skill: linking brand functionality with consumer-based Brand equity". Journal of Product \& Brand Management, 26(5), 477-491.

Molinillo, S., Ekinci, Y., \& Japutra, A. (2019). "A consumer-based brand performance model for assessing brand success". International Journal of Market Research, 61(1), 93-110.

Santoso, I. (2016). "Peran Kualitas Produk dan Layanan, Harga dan Atmosfer Rumah Makan Cepat Saji terhadap Keputusan Pembelian dan Kepuasan Konsumen". Jurnal Manajemen Teknologi, 15(1), 94109.

Sekaran, U., \& Bougie, R. (2013). Research Methods for Business. United Kingdom: Jhon Wiley \& Sons Ltd. 
Sekardila, P. (2016). Pengaruh Inovasi produk Dan Diferensiasi Produk Terhadap Keunggulan Bersaing Pada Sentra Industri Pakaian Anak Pagarsih Bandung. Bandung: Universitas Komputer Indonesia.

Severi, E., \& Ling, K. C. (2013). "The mediating effects of brand association, brand loyalty, brand image and perceived quality on brand equity". Asian Social Science, 9(3), 125-137.

Smith, D. M., Bansal-Travers, M., O'Connor, R. J., Goniewicz, M. L., \& Hyland, A. (2015). "Associations between perceptions of e-cigarette advertising and interest in product trial amongst US adult smokers and non-smokers: Results from an internet-based pilot survey Electronic cigarettes: Towards evidence-based regulation Dr Maciej L. Goniewicz". Tobacco Induced Diseases, 13(1), 1-12.

So, K. K. F., King, C., Hudson, S., \& Meng, F. (2017). "The missing link in building customer brand identification: The role of brand attractiveness". Tourism Management, 59, 640-651.

Srisomthavil, N., \& Assarut, N. (2018). "The impact of perceived counterfeit luxury brand proliferation on luxury brand values and patronage intention". MarketTrziste, 30(1), 41-60.

Story, V. M., Boso, N., \& Cadogan, J. W. (2015). The form of relationship between firmlevel product innovativeness and new product performance in developed and emerging markets. Journal of Product Innovation Management, 32(1), 45-64.

Sugiyono. (2012). Metode Penelitian Kuantitatif, $K$ ualitatif dan R\&D. Bandung: Alfabeta.

Sun, K., Zuo, M., \& Kong, D. (2017). What can product trial offer?: The influence of product trial on Chinese consumers' attitude towards IT product. International Journal of Asian Business and Information Management, 8(1), 24-37.

Swastha, B., \& Irawan. (2000). Manajemen Pemasaran Modern. Yogyakarta: Liberty.

Tanusondjaja, A., Nenycz-Thiel, M., Dawes, J. and Kennedy, R. (2018). "Portfolios: patterns in Brand penetration, market share, and hero product variants". Journal of Retailing and Consumer Services, 41, 211-217.

Tjiptono, F., Chandra, G., \& Adriana, D. (2008). Pemasaran Strategik (1st ed.). Yogyakarta: Andi.
Urde, M. (2016). "The Brand core and its management over time". Journal of Product \& Brand Management, 25(1), 26-42.

Voss, K. E., \& Mohan, M. (2016). "Corporate brand effects in brand alliances". Journal of Business Research, 69(10), 41774184.

Wang, L., \& Finn, A. (2012). Measuring consumer-based brand equity across brand portfolios: Many-facet Item Response Theory perspective. Journal of Targeting, Measurement and Analysis for Marketing, 20(3-4), 254-260.

Weenas, J. R. S. (2013). "Kualitas Produk, Harga, Promosi dan Kualitas Pelayanan Pengaruhnya terhadap Keputusan Pembelian Spring Bed Comforta", 1(4), 607-618.

Yalcinkaya, G. and Aktekin, T. (2015). "Brand extension effects and core attributes of experience product franchises: a Bayesian approach". Journal of Product Innovation Management. 32(5), 731746. 